\title{
Recruiting personnel in a tight labour market: an analysis of employers' behaviour
}

Kène Henkens

Netherlands Interdisciplinary Demographic Institute (NIDI), The Hague,
The Netherlands, and
Chantal Remery and Joop Schippers
Department of Economics, Utrecht University, Utrecht, The Netherlands
Recruiting personnel

421

Received February 2004 Revised December 2004 Accepted February 2005

\begin{abstract}
Purpose - During recent years, the Dutch labour market has developed from a buyers' market into a sellers' market. Consequently employers had to increase their efforts to find suitable staff. This paper aims to analyse the instruments employers use to contact with potential workers. To what extent do employers still rely on traditional means like advertisements in the paper or do they behave more actively, using the world wide web, visiting job fares et cetera.

Design/methodology/approach - The authors conducted a survey among more than 1,000 employers in The Netherlands. Factor analyses and regression analyses are carried out to explain different recruitment strategies.

Findings - The factor analyses show that the different recruitment methods can be traced back to three recruitment strategies. The first strategy was described as active and informal recruitment. The second strategy was called recruiting via the internet and the third is characterised by formal recruitment. The results suggest that many organisations - not in the least organisations in the local government sector - could gain a great deal from using a wider range of instruments to recruit new personnel.

Originality/value - The paper analyses the instruments used by employers in search for potential workers.
\end{abstract}

Keywords Behaviour, Workforce planning, Employers, The Netherlands

Paper type Research paper

\section{Introduction}

This paper looks into the recruitment practices of employers. Various recent studies have shown that a large number of organisations in The Netherlands have faced severe problems finding personnel in recent years (Taris et al., 1999; Bijsterbosch and Nahuis, 2000; Lievens and van Dam, 2001; Remery et al., 2003; Denolf et al., 2002). We know little about how employers are dealing with these problems and are going about recruiting staff. Do they rely primarily on traditional recruitment methods, such as job advertisements in newspapers and magazines? Or are employers, if need be, taking proactive measures to fill their vacant positions, such as using their personnel's social networks? This question is the more relevant since employers in every country that is facing an aging population during the next decade will have to deal with this type of problem as soon as the economy picks up again.

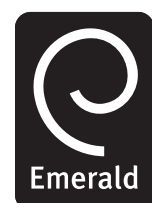

International Journal of Manpower Vol. 26 No. 5,2005 pp. $421-433$

(C) Emerald Group Publishing Limited 0143-7720

DOI 10.1108/01437720510615116 
IJM

26,5

422

Given the supply/demand trends of the past few decades - when the labour market tended to be a buyers' market and a substantial pool of unemployed formed a buffer that could absorb cyclical fluctuations in labour demand - it is hardly surprising that most studies focused on employees' job seeking activities (for an overview, see Devine and Kiefer, 1991; Rouwendal and Bor, 1986; Theeuwes, 1999). Research on the theoretical and empirical dimension of employers' behaviour to find suitable staff, has studied primarily the selection behaviour: how to select personnel from a pool of applicants (Phelps, 1972; Marsden and Campbell, 1990; Russo et al., 2000; Thurow, 1975). Van Ours and Ridder (1992) state that "almost all vacancies are filled from a pool of applicants that is formed shortly after posting the vacancy". Due to the economic expansion of the second half of the 1990s, Dutch employers were increasingly confronted with a situation in which in many occasions no, or only very few applicants responded to vacancies. The number of vacancies almost exceeded the number of unemployed people, after decades of excess in labour supply (Figure 1). Behaviour of employers became increasingly geared toward filling a pool of applicants instead of selecting from the existing pool. In this paper, we study the search intensity of different strategies used by employers to attract applicants. Thereby we do not only look at more traditional search methods, such as posting an ad, but also at the importance of the internet in finding staff. Breaugh and Starke (2000, p. 422) point to the fact that existing recruitment literature has paid far too little attention to the question which employers use particular sources. Therefore, we will not only address the question which recruitment methods employers use to find staff, but we will also investigate whether these methods can be clustered into specific recruitment strategies.

In order to be able to answer the above questions, we conducted extensive data collection (Visser et al., 2003). The data were gathered between February and April 2002 among more than one thousand companies and organisations, building on earlier studies into labour shortages and ageing workforces (Remery et al., 2003).

\section{Theory}

Recruitment and selection are topics that have been put on economic research agendas relatively recently. The general equilibrium approach, which dominated economic theory and theories about the labour market for so long, did incorporate adjustments in

Figure 1.

Unemployment rate and percentage of vacancies in the Dutch labour market 1978-2002.

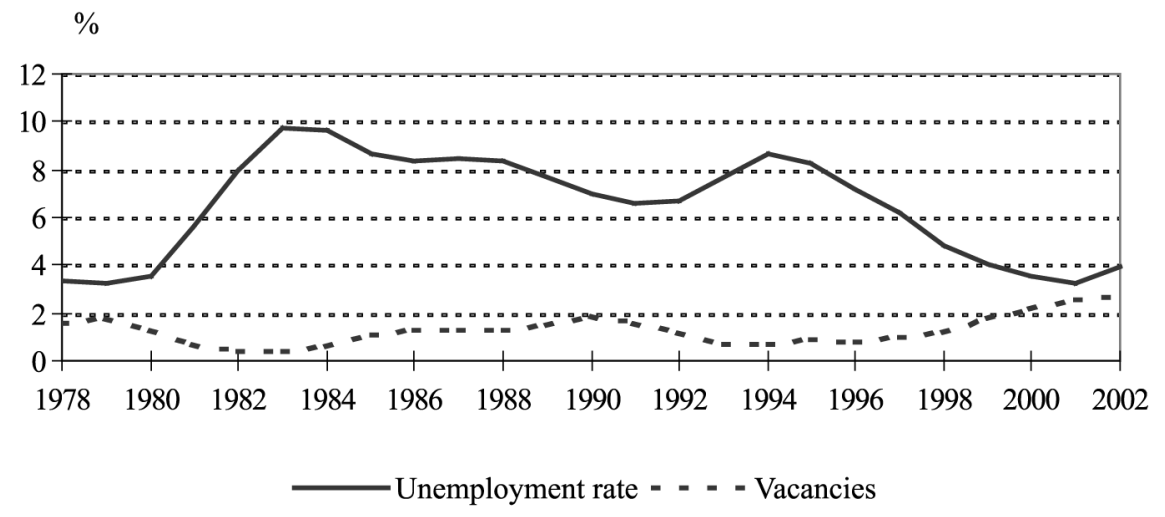

Source: Statistics Netherlands 
labour demand (for example, by offering higher wages, employers were able to attract more staff), mostly using comparative statics. General equilibrium theory did not address the adjustment process from one state of equilibrium to another (Hansen, 1970). Questions such as where the newly employed staff came from and/or how the selection of employees took place, are addressed only when the adjustment process itself forms part of the analysis. It was not until an element of uncertainty was introduced into labour market analyses around 1970, that recruitment and selection issues were given explicit attention (see for an overview and critique Barber, 1998; Breaugh and Starke, 2000), as part of a growing literature on search theory (Phelps, 1970).

\section{Different recruitment methods}

Recruitment activities and channels may be classified in various ways (Marsden and Campbell, 1990). One type of classification focuses on the distinction between active and passive recruitment. In the case of passive recruitment, the organisation waits until an applicant gets in touch with them, such as unsolicited applications. Today, many organisations have websites that contain information for people seeking jobs. In the case of active recruitment, employers actually go in search of potential candidates. They may do so by commissioning recruitment agencies to find candidates, or by searching in databases on the internet where job seekers have posted their curricula vitae. They may also, for example, approach training and education institutes or university professors to get in touch with new graduates or students who have almost completed their studies.

Another classification is based on the distinction between formal and informal recruitment. A type of formal recruitment is posting a job advertisement in a newspaper or magazine. Formal recruitment methods involve the use of some intermediary between the employer and the potential employee. An example of informal recruitment is using the employer's network of contacts (Boxman, 1992). This network could include the personal networks of the existing workforce as well as other employers, people working in the same business or employers in the vicinity. In addition, Marsden and Campbell (1990, p. 60) point to the fact that current employees can act as "preliminary screeners", as they pass on information on job openings to particular members of their network and leave other members uninformed. Like the active/passive criterion, the formal/informal criterion is a sliding scale. Organisations often combine various recruitment methods. The empirical analyses presented in the following will look into the question whether fixed patterns can be discerned in the mix of activities employed.

\section{Explaining recruitment strategies}

Which organisations pursue which recruitment strategies when they go in search of new staff? We expected organisations in the public sector to be most inclined to focus on formal recruitment methods given that politicians require transparency and free access for all in this sector. One would expect active and informal recruitment methods to be applied most frequently in the health and welfare sector. This sector is being confronted with large shortages and traditional recruitment channels do not seem to be effective any longer. Currently, the sector focuses on "seducing" former health workers, e.g. women who withdraw from the labour market due to childbirth, to re-enter the 
IJM

26,5

424

labour market. Networks of former colleagues, friends and neighbours may play an important part in tracing these potential workers and convincing them to accept a job in this sector (again).

A number of factors at the level of individual organisations were also expected to play a role. An important factor in this respect is the perceived difficulties of organisations in finding suitable staff to fill their vacancies. The greater the perceived difficulties, the greater the likelihood that organisations will take a series of co-ordinated measures to recruit more employees, the less they can afford to sit back and wait or follow lengthy, formal procedures, and the more likely they will be to apply active and informal recruitment methods. In addition, organisations may also be influenced by the general tightness of the labour market. The reasoning behind this is that in an environment in which "everyone" faces the problem of a tight labour market, individual employers are likely to be more inclined to recruit actively than in an environment in which labour shortages are less an issue. The composition of their existing workforce may also affect the recruitment strategies opted for by employers. A high percentage of part-time employees is likely to increase the possibility of recruiting employees through the social networks of the existing workforce, given the contacts that these part-timers tend to have in the unpaid activities they pursue.

\section{Methods}

\section{Data}

In Febraury 2002, a questionnaire was sent to over 3,433 companies and organisations with more than nine employees. The names and addresses of the private sector organisations were taken from a sample drawn from the trade register of the Chamber of Commerce. To include organisations in the public sector questionnaires were sent to all Dutch municipalities, general hospitals and nursing homes and homes for the elderly. The total response rate was 31 per cent, which is lower than the average response of individual surveys but substantially higher than the response generally found in corporate surveys. In Europe and the USA, response rates have been found to be at most 20-30 per cent (Brewster et al., 1994; Kalleberg et al., 1996). Response rates in the local government sector (47 per cent) and the health and welfare sector (40 per cent) were higher than in the private sector (24 per cent). The questionnaires were completed by a board member/managing director-owner (33 per cent), middle manager (13 per cent), personnel (54 per cent). About 60 per cent of the respondents were men and their average age was 44 years. The types of industrial sectors varied from the health/welfare sector (30 per cent), the manufacturing/construction sector (23 per cent), and the service sector (banking, transport, insurance, trade, hotels and restaurants) (25 per cent) to the local government (22 per cent).

\section{Measurement}

Staff recruitment. Respondents were able to indicate the degree to which they made use of various methods, such as: "posting a job advertisement in newspapers or magazines", "posting an ad on own website", "responding to unsolicited applications". See Table I for an overview the search methods. The answer categories provided were: "never/hardly ever", "frequently", and "often".

Characteristics of the organisation. The questionnaire included a number of questions about the structural characteristics of the organisation, such as the industrial 


\begin{tabular}{|c|c|c|c|c|}
\hline Recruitment methods & Hardly ever/never & Frequently & Often & $\begin{array}{l}\text { kecruiting } \\
\text { personnel }\end{array}$ \\
\hline \multicolumn{5}{|l|}{ "Passive" recruitment } \\
\hline Job advertisements in newspapers or magazines & 16 & 49 & 35 & \multirow{5}{*}{425} \\
\hline Job advertisements on own web site & 45 & 19 & 36 & \\
\hline Unsolicited applications & 15 & 57 & 28 & \\
\hline Offering traineeships & 23 & 52 & 25 & \\
\hline Outsourcing to temp agency & 38 & 46 & 17 & \\
\hline $\begin{array}{l}\text { Outsourcing to recruitment agency } \\
\text { "Active" recruitment }\end{array}$ & 60 & 31 & 9 & \multirow{11}{*}{$\begin{array}{r}\text { Table I. } \\
\text { Recruitment through } \\
\text { passive and active } \\
\text { methods by organisations } \\
\text { in The Netherlands (in } \\
\text { per cent; } n=1,054 \text { ) }\end{array}$} \\
\hline Using social networks of existing workforce & 23 & 52 & 24 & \\
\hline Approaching institutes of education & 46 & 44 & 10 & \\
\hline Contacting colleagues in other companies & 47 & 44 & 10 & \\
\hline Searching in vacancy databases and/or career sites & 69 & 26 & 6 & \\
\hline Searching through recruitment and industry fairs & 65 & 30 & 5 & \\
\hline Searching in CV databases & 77 & 20 & 4 & \\
\hline \multirow{4}{*}{$\begin{array}{l}\text { Organising special recruitment events } \\
\text { Placing banners and links to own web site to attract } \\
\text { personnel } \\
\text { Spreading information through flyers, free } \\
\text { postcards, beer mats etc. }\end{array}$} & 81 & 16 & 3 & \\
\hline & 87 & 11 & 3 & \\
\hline & & & & \\
\hline & 89 & 9 & 2 & \\
\hline
\end{tabular}

sector in which the organisation operated. Respondents were given a list of industrial sectors according to Eurostat (1990) and were asked to indicate the sector in which their own organisation operated. We categorised the industrial sectors in manufacturing and construction, service sector, local government sector and the health/welfare sector.

Other characteristics of the organisation were a breakdown of the workforce by age and level of education. With respect to age, respondents were asked to give the percentage of the employees aged " 50 and older". Similarly, they were asked to give the percentage of employees with "higher vocational education or university". The questionnaire also asked for the percentage of staff working part-time.

In order to gain insight into the level of competition faced by the organisations concerned, respondents were asked to indicate whether their organisation operated in a competitive market. The answer categories were: "yes, we operate in a strongly competitive market", "yes, we operate in a fairly competitive market", "there is a market, but competition is almost absent", and "there is no market".

Labour market situation. The degree of perceived tightness in the labour market was measured by asking respondents to what extent they had encountered problems finding staff. The answer categories were: "with a relatively large number of positions", "with some positions", and "hardly ever". The unemployment rate within the local labour market region (we distinguish between 40 regions in The Netherlands) in which the organisation was based, was added to the database as an indicator of the labour market situation faced by the companies in the region concerned[1].

\section{Analysis}

Factor analysis was carried out to identify the relationship between the 15 different recruitment methods, and to find out whether this relationship can be expressed in terms of a number of dimensions. Principal components analysis is a statistical 
IJM

26,5

426

technique that linearly transforms an original set of variables into a substantially smaller set of uncorrelated variables that represent most of the information in the original set of variables (Dunteman, 1989).

Factor analysis has been carried out with principal components analysis and promax rotation. Promax rotation is a kind of oblique rotation where correlation between the factors is permitted (Dunteman, 1989). Since organisations hardly ever use one recruitment channel only, it is reasonable to assume that the recruitment factors will correlate with one another. The simplicity of the rotated factor loading matrix makes interpretation easier. The factor scores are calculated as a factor loading-weighted average of all items.

For the explanatory analyses, we used multivariate regression analysis. The dimensions of the recruitment strategies were used as dependent variables and the organisational and labour market characteristics were used as independent variables. Respondents' age, sex and function within the organisation are included as control variables.

The presented coefficients are standardised regression coefficients, which gives the effect on the dependent variable of a standard deviation change in each explanatory variable, and hence is independent of the units of the independent variable. The use of standardised regression coefficients enables the reader to compare the magnitudes of the effects throughout the table.

\section{Results}

\section{How do organisations recruit?}

Table I gives an overview of the recruitment methods used by the organisations in our survey. The most common recruitment method in The Netherlands is placing an ad in a newspaper or magazine: 84 per cent of the organisations were found to use this method frequently to often. This result is similar to what Marsden (1994) has found for the USA. Posting vacancies on the internet has also become a common recruitment method: more than one-third of the organisations said they used this method often and 19 per cent did so frequently. Having said that, as many as 45 per cent of the organisations said they never made use of the internet for recruitment purposes. A total of 85 per cent of the organisations said they found staff through unsolicited applications. Offering traineeships was also a common recruitment method (77 per cent).

A majority of organisations (63 per cent) called in the assistance of temp agencies to fill vacancies, either temporarily or permanently. Outsourcing the recruitment of personnel entirely to specialised recruitment agencies was found to be less common: less than 10 per cent of the respondents said they did so frequently.

In summary, we can say that using unsolicited applications and advertising in the press were the most popular traditional, "passive" recruitment methods.

In the category "active recruitment activities", making use of the social network of the existing workforce appeared to be the most commonly used method. More than half the organisations surveyed (52 per cent) were found to frequently use these networks, and almost one-quarter did so often (24 per cent). Approaching potential employees may start by approaching institutes of education. More than half the respondents said they used this method (54 per cent). A third recruitment technique that scored well in the survey is contacting other organisations in the same industrial sector with a view 
to jointly finding a solution to their staffing problems. This may lead to initiatives such as setting up a flexpool of employees, joint recruitment campaigns or open days.

There are also other ways in which organisations can get in touch with potential candidates. One such method is taking part in recruitment fairs or industry fairs, where companies are able to present themselves and raise their profile as an attractive employer, without focusing on specific vacancies. Events of this kind also offer companies the opportunity of forging informal contacts with potential employees. More than one third of the organisations (35 per cent) said they used this method in an effort to recruit staff.

The advent of the internet has created new opportunities for staff recruitment, such as searching for new employees in curriculum vitae databases. Potential candidates are able to post their CVs on the internet, allowing employers to access these CVs. Almost one quarter of the organisations surveyed (24 per cent) said they used this method. A more frequently used method is visiting vacancy databases and/or career sites (31 per cent).

\section{Recruitment methods: in search of strategies}

The preceding section has described the various recruitment methods used by organisations. In this section, we shall investigate whether we can identify patterns in the recruitment methods described. We carried out factor analysis to answer the above questions. The results of the factor analysis (Table II) show that the recruitment methods may be divided into three main recruitment strategies, which together account for over 42 per cent of the total variation in recruitment methods used.

Strategy 1: Active and informal recruitment. The first strategy may be described as "active and informal recruitment of new employees". We found that 24 per cent of the variance in recruitment methods was related to this factor and that this strategy was strongly linked to items such as approaching institutes of education for new graduates,

\begin{tabular}{lcrr}
\hline Recruitment methods & Active and informal & Internet & Formal \\
\hline Job advertisements in newspapers or magazines & -0.04 & 0.10 & 0.36 \\
Job advertisements on own web site & -0.10 & 0.36 & 0.55 \\
Searching in CV databases on the internet & -0.11 & 0.89 & -0.04 \\
Approaching institutes of education & 0.58 & 0.17 & -0.01 \\
Searching in vacancy databases and/or career sites & 0.05 & 0.80 & -0.08 \\
Contacting colleagues in other companies & 0.16 & 0.31 & 0.05 \\
Unsolicited applications & 0.65 & -0.00 & -0.19 \\
Using social networks of existing workforce & 0.56 & 0.08 & -0.10 \\
Outsourcing to recruitment agencies & 0.00 & -0.05 & 0.76 \\
Offering traineeships & 0.64 & -0.07 & 0.02 \\
Outsourcing to temp agencies & 0.04 & -0.20 & 0.76 \\
Searching through recruitment and industry fairs & 0.62 & 0.07 & 0.07 \\
Organising special recruitment events & 0.72 & -0.04 & 0.07 \\
Spreading information through flyers, free & & & \\
postcards, beer mats etc. & 0.54 & -0.09 & 0.08 \\
Placing banners and links to own web site to attract & & & \\
personnel & 0.15 & 0.36 & 0.27 \\
Eigenvalue & 2.98 & 2.26 & 1.88 \\
$R^{2}$ & & 42.70 & \\
\end{tabular}

\section{Recruiting personnel}

427

\section{,}


IJM

26,5

428

using the social network of the existing workforce, offering traineeships, searching through recruitment fairs and industry fairs.

Organisations that score well on this dimension tend to develop a whole host of activities in their search for new staff. They are the ones who take the initiative and they make use of all kinds of contacts to find new employees. Interestingly, many of these activities focus on the recruitment of young workers.

Strategy 2: Recruiting via the internet. The second strategy could be described as "actively searching for employees via the internet". In this strategy, the following items scored well: posting an ad on one's own web site, searching in CV databases on the internet, searching in vacancy databases and/or career sites, and placing banners and links to own website to attract potential employees.

"Recruiting via the internet" has become a clearly identifiable, separate recruitment strategy among employers. We expect that the employers who use this new strategy, which was not available until the emergence of the internet during the last decade of the twentieth century, constitute a specific group, mainly active in the commercial services sector, who tend to be in search of highly educated employees.

Strategy 3: Formal recruitment. The third strategy could be described as "searching for staff via formal channels, by outsourcing the recruitment process and/or advertising in newspapers". In the latter category, the following items scored well: placing an advertisement in newspapers or magazines, posting an ad on own web site, outsourcing to recruitment agencies and recruiting to temp agencies.

Organisations that apply this recruitment strategy place the initiative with the applicants, who may choose to react or not to react to a job advertisement, or with a third, specialised party. In the latter case, the third party takes over the search activities from the employer - usually putting in an extra effort - and their expertise is often called in for cases that are expected to be particularly difficult.

The results of the regression analyses to explain the use of the three different strategies are shown in Table III. The intensity of the three recruitment strategies have been used as dependent variables. An additional analysis was carried out in which the totality of all activities was defined as the dependent variable[2]. This is in line with earlier research (Russo et al., 2000) in which recruitment efforts were measured as a single dimension.

As shown in the first column of Table III, marked differences exist between industrial sectors in the extent to which organisations recruit actively. Table III shows quite clearly that, as expected, organisations that face more serious staffing problems tend to recruit more actively. Having said that, employers' behaviour was also found to be affected by the general regional labour market situation. This implies that employers are conscious of the fact that organisations in regions with a low level of unemployment, irrespective of any specific staffing problems within their own organisation, need to make an extra effort to recruit personnel[3] since there are many other organisations competing for the available candidates. The role played by competition is also reflected in the fact that organisations that face strong competition tend to recruit staff more actively. The size of organisations was also found to have a positive impact on the active and informal recruitment efforts made by employers.

The size of the organisation and the staffing problems faced by organisations were also found to influence the two other recruitment strategies. The bigger an organisation and the greater the staffing problems faced, the greater the resources used 


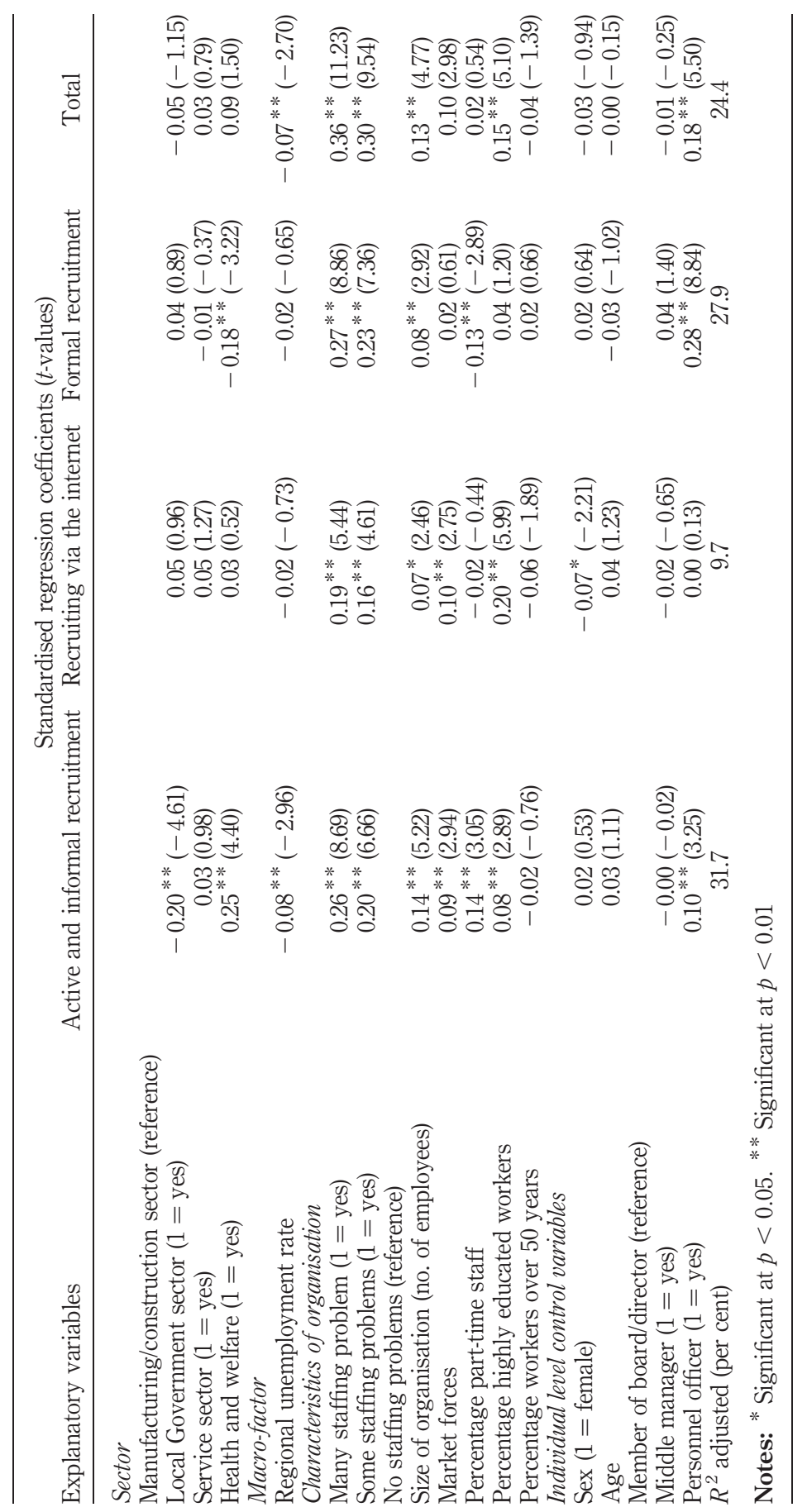

Recruiting personnel

429

Table III.

Results of regression analyses to explain the extent to which organisations use formal or informal methods or the internet as a recruitment strategy 
IJM

26,5

430 to recruit personnel, not only "actively and informally" but also "through the internet", or through more "formal" channels. These results suggest that small organisations that face staffing shortages are at a disadvantage in their recruitment efforts compared with large organisations. "Recruiting via the internet" is - as was to be expected used relatively often in the service sector and is also found in organisations with a highly educated workforce. A competitive market also appeared to stimulate the use of the modern media in recruitment activities.

And finally, we found that while "formal" recruitment strategies in the health and welfare sector were used relatively rarely, large organisations and organisations that face staffing problems are more likely to use this strategy.

With respect to the effects of individual level control variables we establish that personnel officers report more recruitment activities with regard to formal recruitment and informal and active recruitment. Females report less internet recruitment.

If we compare the results of the analyses using separate dimensions with the results obtained when we view all recruitment methods as one single dimension, we see that the differences that exist between the various sectors are underestimated in the one-dimensional approach. In particular, differences between local government sector and the health and welfare sector were accentuated: whereas local government tended to use formal recruitment channels (in almost 100 per cent of the cases they placed a job advertisement), active and informal recruitment were far less common among local authorities and were more widely used in the health and welfare sector. These results imply that distinguishing between different dimensions of recruitment behaviour or as we have labelled it - distinguishing between different strategies, adds to our understanding of organisational behaviour in the field of recruitment and staffing.

\section{Summary and conclusions}

The most commonly used recruitment method of Dutch employers is to place an advertisement in a newspaper or magazine. This passive method is applied frequently to often by 84 per cent of the employers. A form of active recruitment that was applied by a majority of organisations was using the social networks of the existing workforce. The different recruitment methods have been reduced to three recruitment strategies with the aid of factor analyses. The first strategy was described as active and informal recruitment. The second strategy was called recruiting via the internet and the third is characterised by formal recruitment.

If we look at industrial sectors, we see that organisations in the local government sector are clearly less inclined to use active and informal strategies than organisations in all other industrial sectors. Active and informal recruitment is most common in the health and welfare sector. Organisations in the local government sector tend to use passive and formal methods of recruiting.

Based on the theoretical insights presented earlier, one would expect employers in organisations that face major staffing problems to actively go in search of personnel. This hypothesis was confirmed. Having said that, most organisations still mainly use traditional and formal recruitment methods. They place a job ad and hope that one of the responding candidates can be selected. If this method does not yield a suitable candidate, employers will recruit more actively, primarily by using the social networks of the existing workforce. Other methods applied are approaching institutes of education and, to a lesser extent, participating in recruitment fairs and organising their 
own recruitment events. Our analyses have shown that the use of modern media such as the internet constitutes a separate recruitment strategy, alongside traditional recruitment methods and active methods. An important conclusion with relevance in regard to the ageing of the labour force is that the active recruitment activities are biased towards the youth; probably reflecting employers' preferences for recruiting younger workers. Older workers may to a large extent be dependent on the formal recruitment channels. This may hamper the already poor employment prospect of older unemployed workers, even in the case of labour shortages (Henkens et al., 1996; Remery et al., 2003).

Important questions for future research are how employers think about specific recruitment methods and how effective these instruments are for recruiting potential workers from different groups for different jobs and occupations. In this respect, it should be noted that staffing problems might also be the result of the wrong recruitment strategy (Van Ours and Ridder, 1992). This issue, however, is beyond the scope of our research. Do government organisations have little contact with institutes of education because they expect little from this recruitment approach, or do they lack the resources to maintain such contacts? How does the percentage of employees recruited via the internet relate to the percentage recruited through advertisements? Answers to these and other questions could provide more insight into the extent to which a wider range of recruitment methods could promote the best possible allocation of labour.

\section{Notes}

1. Note, however, that not all organisations depend on the local labour market to the same extent. The better educated in particular, rely more on the national labour market than on a local or regional market.

2. This variable was constructed by adding up all recruitment methods used. The variable was transformed in $Z$-scores to simplify comparison with the other analyses.

3. In this respect, one could speak of a "stimulating factor" in the recruitment behaviour of employers. Conversely, a high level of unemployment can have a discouraging effect on the search efforts of employees. High unemployment may even discourage employees to the extent that they stop their search efforts altogether (Henkens et al., 1996).

\section{References}

Barber, A.E. (1998), Recruiting Employees, Sage, Thousand Oaks, CA.

Bijsterbosch, M.G. and Nahuis, N.J. (2000), "Krapte op de arbeidsmarkt: Beleidsinitiatieven gewenst", Economische Statistische Berichten, Vol. 85, pp. 920-8.

Boxman, E.A.W. (1992), Contacten en Carrière. Een Empirisch Theoretisch Onderzoek Naar de Relatie Tussen Sociale Netwerken en Arbeidsmarktposities, Thesis Publishers, Amsterdam.

Breaugh, J.A. and Starke, M. (2000), "Research on employee recruitment: so many studies, so many remaining questions", Journal of Management, Vol. 26 No. 3, pp. 405-34.

Brewster, C., Hegewisch, A., Mayne, L. and Tregaskis, O. (1994), "Methodology of the Price Waterhouse Cranfield Project", in Brewster, C. and Hegewisch, A. (Eds), Policy and Practice in European Human Resource Management, Routledge, London, pp. 230-45.

Denolf, L., Denys, J. and Simoens, P. (2002), Hoe Werven Bedrijven in België?, Leuven, HIVA-KU Leuven, Leuven/Upedi, Leuven/Brussel. 
IJM

26,5

432
Devine, T.J. and Kiefer, N.M. (1991), Empirical Labor Economics, Oxford University Press, New York, NY.

Dunteman, G.H. (1989), Principal Components Analysis, Series: Quantitative Applications in the Social Sciences, Sage University Papers 69, Sage, Newbury Park, London, New Delhi.

Eurostat (1990), Statistical Classification of Economic Activities in the European Community, Rev. 1, Luxembourg.

Hansen, B. (1970), A Survey of General Equilibrium Systems, Wiley, New York, NY.

Henkens, K., Sprengers, M. and Tazelaar, F. (1996), "Unemployment and the older worker in The Netherlands: re-entry in the labour force or resignation", Ageing and Society, Vol. 16 No. 5, pp. 561-78.

Kalleberg, A.L., Knoke, D., Marsden, P. and Spaeth, J. (1996), Organizations in America: Analyzing Their Structures and Human Resource Practices, Sage, London.

Lievens, F. and van Dam, K. (2001), "Nieuwe vragen en uitdagingen bij werving en selectie", Gedrag en Organisatie, Vol. 14, pp. 36-47.

Marsden, P.V. (1994), “The hiring process”, American Behavioral Scientist, Vol. 37, pp. 979-91.

Marsden, P.V. and Campbell, K.E. (1990), "Recruitment and selection processes: the organizational side of job searches", in Breiger, R.L. (Ed.), Social Mobility and Social Structure, Cambridge University Press, Cambridge, MA.

Phelps, E.S. (1970), Microeconomic Foundations of Employment and Inflation Theory, Macmillan, London.

Phelps, E.S. (1972), "The statistical theory of racism and sexism”, American Economic Review, Vol. 62, pp. 659-61.

Remery, C., Henkens, K., Schippers, J.J. and Ekamper, P. (2003), "Managing an aging workforce and a tight labor market: views held by Dutch employers", Population Research and Policy Review, Vol. 22, pp. 21-40.

Rouwendal, J. and Bor, K.B. (1986), "Zoekgedrag op de arbeidsmarkt”, Economische Statistische Berichten, Vol. 71, pp. 1051-5.

Russo, G., Rietveld, P., Nijkamp, P. and Gorter, C. (2000), "Search channel use and firms' recruitment behaviour", De Economist, Vol. 148, pp. 373-93.

Taris, T., Blokker, M., Bok, I., Born, M. and van der Flier, H. (1999), "Van selectie naar werving?: Over het aantrekken van personeel op een krappe arbeidsmarkt”, De Psycholoog, Vol. 43, pp. 560-4.

Theeuwes, J.J.M. (1999), "Gezocht: luizebaan. Een overzicht van theorieën van het zoeken en vinden van een baan”, Economisch Statistische Berichten, Vol. 84 No. 4201, pp. DZ9-DZ10.

Thurow, L.C. (1975), Generating Inequality, Basic Books, New York, NY.

Van Ours, J. and Ridder, G. (1992), "Vacancies and the recruitment of new employees", Journal of Labor Economics, Vol. 2 No. 10, pp. 138-55.

Visser, P., Remery, C., Henkens, K. and Schippers, J. (2003), Hoe Werven Werkgevers? Structurele Aanpak Knelpunten Personeelsvoorziening in Nederland, Publicatie A193, Organisatie voor Strategisch Arbeidsmarktonderzoek, Tilburg.

\section{Further reading}

Gravel, F. (2001), "Differentiation of skills, firms' recruitment strategy and unemployment benefits in an efficiency wage model”, De Economist, Vol. 149, pp. 347-64. 
Sprengers, M. (1992), Explaining Unemployment Duration: An Integrative Approach, Dissertatie Rijksuniversiteit Utrecht, Utrecht.

Recruiting personnel

Appendix

Promax rotation is a kind of oblique rotation where correlation between the factors is permitted.

The correlation matrix is given as follows in Table AI.

433

\begin{tabular}{|c|c|c|c|}
\hline Factors & 1 & 2 & 3 \\
\hline 1 & 1.00 & & \\
\hline 2 & 0.30 & 1.00 & \\
\hline 3 & 0.15 & 0.19 & 1.00 \\
\hline
\end{tabular}

